\title{
CHEMOSPHERE
}

\section{Atmospheric mercury monitoring survey in Beijing, China}

\author{
Shili Liu ${ }^{\text {a }, ~ F a r h a d ~ N a d i m ~}{ }^{\text {a,* }}$, Chris Perkins ${ }^{\text {a }}$, Robert J. Carley ${ }^{\text {a }}$, \\ George E. Hoag ${ }^{\mathrm{a}}$, Yuhan Lin ${ }^{\mathrm{b}}$, Letian Chen ${ }^{\mathrm{b}}$ \\ ${ }^{a}$ The Environmental Research Institute, University of Connecticut, Longley Building, Box Unit 5210, \\ 270 Middle Turnpike (Route. 44), Storrs, CT 06269-3210, USA \\ ${ }^{\mathrm{b}}$ Research Center for Eco-Environmental Sciences, Chinese Academy of Sciences, Academia Sinica, 18 Shuang Quing Road, \\ Haidian P.O. Box 2871, Beijing 100085, China
}

Received 18 May 2001; received in revised form 2 January 2002; accepted 10 January 2002

\begin{abstract}
With the aid of one industrial, two urban, two suburban, and two rural sampling locations, diurnal patterns of total gaseous mercury (TGM) were monitored in January, February and September of 1998 in Beijing, China. Monitoring was conducted in six (two urban, two suburban, one rural and the industrial sites) of the seven sampling sites during January and February (winter) and in four (two urban, one rural, and the industrial sites) of the sampling locations during September (summer) of 1998. In the three suburban sampling stations, mean TGM concentrations during the winter sampling period were $8.6,10.7$, and $6.2 \mathrm{ng} / \mathrm{m}^{3}$, respectively. In the two urban sampling locations mean TGM concentrations during winter and summer sampling periods were $24.7,8.3,10$, and $12.7 \mathrm{ng} / \mathrm{m}^{3}$, respectively. In the suburban-industrial and the two rural sampling locations, mean mercury concentrations ranged from $3.1-5.3 \mathrm{ng} / \mathrm{m}^{3}$ in winter to $4.1-7.7 \mathrm{ng} / \mathrm{m}^{3}$ in summer sampling periods. In the Tiananmen Square (urban), and Shijingshan (suburban) sampling locations the mean TGM concentrations during the summer sampling period were higher than winter concentrations, which may have been caused by evaporation of soil-bound mercury in warm periods. Continuous meteorological data were available at one of the suburban sites, which allowed the observation of mercury concentration variations associated with some weather parameters. It was found that there was a moderate negative correlation between the wind speed and the TGM concentration at this suburban sampling location. It was also found that during the sampling period at the same site, the quantity of TGM transported to or from the sampling site was mainly influenced by the duration and frequency of wind occurrence from certain directions. (c) 2002 Elsevier Science Ltd. All rights reserved.
\end{abstract}

Keywords: Atmospheric mercury; Beijing; China; Rural; Urban

\footnotetext{
${ }^{*}$ Corresponding author. Tel.: +1-860-486-4015; fax: +1-860486-5488.

E-mail addresses: sliu@aqua.eri.uconn.edu (S. Liu), fnadim@aqua.eri.uconn.edu (F. Nadim), cperkins@aqua.eri. uconn.edu (C. Perkins), rcarley@aqua.eri.uconn.edu (R.J. Carley),ghoag@aqua.eri.uconn.edu (G.E. Hoag).
}

\section{Introduction}

Mercury occurs in several different geochemical forms, including elemental $\left(\mathrm{Hg}^{0}\right)$, ionic (oxidized; $\mathrm{Hg}(\mathrm{II})$, speciated; $\mathrm{Hg}^{2+}$ ), and organic (methylmercury; $\mathrm{CH}_{3} \mathrm{Hg}^{+}$) mercury. Mercury in atmosphere is mostly in the form of elemental mercury vapor. Due to its volatility and chemical stability, elemental mercury emissions can circulate in the atmosphere for 1-2 years, allowing its wide dispersion and long-distance transportation (Lin and Pehkonen, 1999). Atmospheric 
mercury originates from natural and anthropogenic sources (Fitzgerald et al., 1998). Natural sources include volcanoes, natural mercury deposits, and volatilization from the oceans. Fifty to seventy-five percent of mercury emission to the atmosphere is related to human activities (Nriagu and Pacyna, 1988; Nriagu, 1989; Xu et al., 1999). Major anthropogenic sources of mercury emission worldwide are: combustion of fossil fuel and coal, municipal waste combustors, sewage sludge and medical waste incinerators, mining activities, electric utility boilers, and manufacturing sources (Nriagu and Pacyna, 1988; Tatsutani, 1998). China is the world's third largest producer of energy and consumed 1.36 billion metric tons of coal in 1997 (59\% more than 1987). Coal use in China could double the present rates by the year 2015 (Godley, 1997).

This paper presents a short-term monitoring study of total gaseous phase mercury (TGM) in Beijing, China, that was a result of a joint cooperation between the Environmental Research Institute of the University of Connecticut and the Research Center for Eco-Environmental Sciences of the Chinese Academy of Sciences. The continuous monitoring technique allowed the observation of more detailed diurnal pattern of atmospheric mercury pollution that had not been observed before in the Beijing area.

\section{Experimental methods}

\subsection{Sampling locations}

Based on the zoning plan defined by the authorities of Beijing municipality, all sampling locations encircled in the city boundaries were classified as urban sites. The suburban sampling sites were located within a radius of $20 \mathrm{~km}$ of the city center and the city boundaries. The rural sites were all beyond the suburban boundary limits and the land was mainly used for agricultural activities. To represent urban-industrial, urban-residential and rural habitats of Beijing, seven sampling sites were selected for ambient mercury monitoring (Fig. 1, Table 1). Site 1 was in Tiananmen Square, which is a tourist area located in the center of Beijing about $30 \mathrm{~m}$ east of the Tiananmen Gateway. Site 2 was in Xuanwu district (Xiaxiejie Street), which is located about $3 \mathrm{~km}$ southwest of the city center. Site 3 was in Shijingshan, which is near the eastern entrance of the Capital Iron Steel Plant complex and was located about $20 \mathrm{~km}$ west of the city. Sites 4 and 5 were located at the Research Center for Eco-Environmental Sciences of the Chinese Academy of Sciences, which is located $12 \mathrm{~km}$ northwest of Beijing in a suburban area. Site 4 was situated in a laboratory on the fourth floor of the main building. Outdoor air samples were taken through the laboratory window.

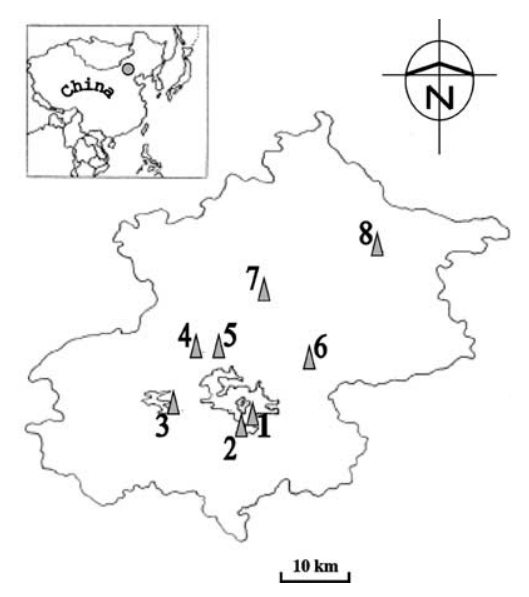

Fig. 1. Beijing municipality and the sampling locations: (1) Tiananmen Square, (2) Xuanwu, (3) Shijingshan, (4) Research Center-1, (5) Research Center-2, (6) Atmospheric Research Institute, (7) Changping, (8) Huairou.

This sampling location was about $12 \mathrm{~m}$ above the ground level. Site 5 was placed at the ground level on a paved area behind the building. Site 6 was at the Institute of Atmospheric Physics of Chinese Academy of Sciences, which is a suburban area located about $9 \mathrm{~km}$ north of Beijing. A weather station capturing continuous meteorological data (wind speed, wind direction, temperature and humidity) at every $20 \mathrm{~s}$ was located at this site. No tall buildings were located in the vicinity of site 6. Site 7 was in Changping, which is a rural site located about $40 \mathrm{~km}$ north of Beijing. Site 8 was in Huairou, which is another rural site located about $60 \mathrm{~km}$ northeast of Beijing.

\subsection{Instrumentation}

A Tekran Model 2537A (Tekran Inc., Toronto, Canada) ambient vapor analyzer was used for this study. This vapor analyzer provided continuous ambient monitoring of TGM with a detection limit of $0.2 \mathrm{ng} / \mathrm{m}^{3}$. Every $5 \mathrm{~min}, 7.51$ of air sample were collected on a cartridge packed with gold-coated particles and subsequently analyzed with cold atomic fluorescence method. The TGM concentration values along with calibration data and operation conditions were transferred to a personal computer through the RS-232 port of the mercury analyzer.

\subsection{Quality assurancelquality control}

The Tekran instrumentation was equipped with a built-in mercury permeation source and was able to automatically calibrate itself at preset time intervals. Each time the instrument was set up in the field, it ini- 
Table 1

Descriptive statistics of atmospheric mercury concentrations for seven sampling locations in Beijing area

\begin{tabular}{|c|c|c|c|c|c|c|c|c|}
\hline Site \# & Site location & Site category & $\begin{array}{l}\text { Sampling } \\
\text { dates (1998) }\end{array}$ & Mean & S.D. & Min. & Max. & $\begin{array}{l}\text { Occurrence } \\
\text { time }^{\mathrm{a}}\end{array}$ \\
\hline \multirow[t]{4}{*}{1} & $\begin{array}{l}\text { Tiananmen Square } \\
\text { (winter-daytime) }\end{array}$ & City center & Feb. $16-20$ & 7.9 & 2.6 & 4.5 & 16.9 & 9:00 AM \\
\hline & $\begin{array}{l}\text { Tiananmen Square } \\
\text { (winter-nighttime) }\end{array}$ & & Feb. 16-20 & 8.6 & 4.2 & 3.8 & 19.5 & 8:00 PM \\
\hline & $\begin{array}{l}\text { Tiananmen Square } \\
\text { (summer-daytime) }\end{array}$ & & Sep. 1-3 & 13.8 & 3.6 & 5.8 & 22.2 & 12:00 PM \\
\hline & $\begin{array}{l}\text { Tiananmen Square } \\
\text { (summer-nighttime) }\end{array}$ & & Sep. 1-3 & 11.4 & 2.6 & 7.6 & 17 & 3:00 AM \\
\hline \multirow[t]{4}{*}{2} & Xuanwu (winter-daytime) & Urban residential & Jan. $21-24$ & 11.6 & 13.3 & 5 & 87 & 9:00 AM \\
\hline & $\begin{array}{l}\text { Xuanwu } \\
\text { (winter-nighttime) }\end{array}$ & & Jan. $21-24$ & 34.9 & 36.2 & 2.5 & 120 & 11:00 PM \\
\hline & $\begin{array}{l}\text { Xuanwu } \\
\text { (summer-daytime) }\end{array}$ & & Sep. $4-8$ & 8.1 & 3.4 & 4 & 19.6 & 8:00 AM \\
\hline & $\begin{array}{l}\text { Xuanwu } \\
\text { (summer-nighttime) }\end{array}$ & & Sep. $4-8$ & 12.1 & 6.3 & 5.8 & 31 & 10:00 PM \\
\hline \multirow[t]{4}{*}{3} & $\begin{array}{l}\text { Shijingshan } \\
\text { (winter-daytime) }\end{array}$ & $\begin{array}{l}\text { Suburban, } \\
\text { industrial }\end{array}$ & Feb. 4-9 & 5.3 & 1.2 & 2.6 & 8.1 & 10:00 AM \\
\hline & $\begin{array}{l}\text { Shijingshan } \\
\text { (winter-nighttime) }\end{array}$ & & Feb. 4-9 & 5.3 & 2.4 & 2.5 & 14 & 11:00 PM \\
\hline & $\begin{array}{l}\text { Shijingshan } \\
\text { (summer-daytime) }\end{array}$ & & Sep. $10-15$ & 7.3 & 2 & 4.4 & 11 & 11:00 AM \\
\hline & $\begin{array}{l}\text { Shijingshan } \\
\text { (summer-nighttime) }\end{array}$ & & Sep. $10-15$ & 9 & 4.2 & 2 & 21.2 & $12: 00 \mathrm{AM}$ \\
\hline \multirow[t]{2}{*}{4} & $\begin{array}{l}\text { Research Center } 1 \\
\text { (winter-daytime) }\end{array}$ & Suburban & Jan. $12-14$ & 8.7 & 3.8 & 4.8 & 18.8 & 1:00 PM \\
\hline & $\begin{array}{l}\text { Research Center } 1 \\
\text { (winter-nighttime) }\end{array}$ & & & 8.4 & 2.6 & 4.8 & 14 & 10:00 PM \\
\hline \multirow[t]{2}{*}{5} & $\begin{array}{l}\text { Research Center } 2 \\
\text { (winter-daytime) }\end{array}$ & Suburban & $\begin{array}{l}\text { Jan. } 30-\text { Feb. } \\
4\end{array}$ & 8.6 & 5 & 3.9 & 35 & 9:00 AM \\
\hline & $\begin{array}{l}\text { Research Center } 2 \\
\text { (winter-nighttime) }\end{array}$ & & & 12.4 & 8.8 & 3.4 & 45 & 8:00 PM \\
\hline \multirow[t]{2}{*}{6} & $\begin{array}{l}\text { Atmospheric Research } \\
\text { Institute (winter-daytime) }\end{array}$ & Suburban & Jan. $16-21$ & 6.1 & 2.7 & 3.5 & 14.6 & 10:00 AM \\
\hline & $\begin{array}{l}\text { Atmospheric Research } \\
\text { Institute } \\
\text { (winter-nighttime) }\end{array}$ & & & 6.4 & 3.1 & 3 & 13.8 & 1:00 AM \\
\hline \multirow[t]{2}{*}{7} & $\begin{array}{l}\text { Changping } \\
\text { (summer-daytime) }\end{array}$ & Rural & Sep. $16-20$ & 5 & 1.6 & 2.5 & 7.7 & 11:00 AM \\
\hline & $\begin{array}{l}\text { Changping } \\
\text { (summer-nighttime) }\end{array}$ & & Sep. 16-20 & 3.7 & 1.7 & 1.7 & 7.1 & 5:00 AM \\
\hline \multirow[t]{2}{*}{8} & $\begin{array}{l}\text { Huairou County } \\
\text { (winter-daytime) }\end{array}$ & Rural & Feb. $10-13$ & 3.6 & 1 & 2.2 & 5.3 & 11:00 AM \\
\hline & $\begin{array}{l}\text { Huairou County } \\
\text { (winter-nighttime) }\end{array}$ & & Feb. $10-13$ & 2.5 & 0.7 & 1.7 & 4.5 & 8:00 PM \\
\hline
\end{tabular}

All concentrations are reported in $\mathrm{ng} / \mathrm{m}^{3}$.

${ }^{\text {a }}$ Time of maximum concentration occurrence.

tiated with a cleaning procedure to establish a blank and was followed by initial calibration. The instrument was programmed to automatically calibrate itself every $24 \mathrm{~h}$ in the field at 12:00 PM. The duration of autocalibration was $20 \mathrm{~min}$, and the generated calibration data were reviewed for any significant changes. The response factor changes were all below $15 \%$ (the preset acceptance criterion). After completion of the calibration 
procedure, no stepwise shifts in the TGM measurements were observed which indicated that the Tekran system remained stable during operation.

Prior to being used for TGM measurements in the Beijing urban and suburban areas, the Tekran instrumentation was used by our research team at two of eight Connecticut sampling locations (East Hartford and Mohawk Mountain) that were set to continuously measure the levels of gaseous atmospheric mercury in Connecticut. The Tekran instrument provided a QA/QC check for the field and laboratory methods that were being used at these sampling stations. The 5-min interval samples were averaged over a week period and the results were compared with the weekly gold trap/GCCVAA analyzed samples (details of the Connecticut long-term mercury monitoring study and the QA/QC for that study can be found in Nadim et al., 2001). The comparison results were tabulated in Table 2 . The results in Table 2 depict a good agreement between the mean weekly TGM concentrations measured with the two different methods and validate Tekran's field operating procedure.

The long-term investigation study of atmospheric mercury contamination in Connecticut indicated that $24 \mathrm{~h}$ was a sufficient interval for the Tekran instrument's calibration.

\subsection{Meteorological data (data analysis)}

Winds were categorized according to wind direction by dividing the azimuth $\left(0-360^{\circ}\right)$ into 36 zones, clockwise from the north with $10^{\circ}$ intervals. A correlation analysis was conducted to address the association of atmospheric mercury concentrations with wind speed and wind direction distribution. The 5-min weather data were used to study the correlation between ambient concentration of mercury and weather parameters.

Samples taken during January and February were classified as winter samples and samples taken during September were considered as summer samples. TGM was continuously monitored from three to six days at each sampling location (Table 1).

\section{Results}

\subsection{Hourly variations of TGM in winter and summer sampling periods}

To present the data, 5-min samples were transformed to hourly concentrations of mercury by averaging over 60 -min periods. Descriptive statistics of atmospheric mercury concentrations for the seven sampling locations in Beijing area are presented in Table 1.

During the winter sampling period, mean concentration of mercury at the urban residential site (Xuanwu) was more than twice the concentration of mercury at all other sampling locations. In this sampling location, there were two episodes (about $10 \mathrm{~h}$ ) of high mercury concentrations, when mean TGM concentrations were reached and exceeded $100 \mathrm{ng} / \mathrm{m}^{3}$ (Fig. 2). This phenomenon contributed to high values of mean concentration of mercury during the monitoring period. In the Xuanwu sampling location, there were many traditional one-story residential houses. Almost every house had its own coal-burning furnace for heating in winter. Houses in the Beijing area are traditionally one-story high with a chimney that extends $\sim 1-2$ m horizontally away from the building's roof. Most households in the Beijing area, and in China in general, use coal for heating purposes during cold periods and they account for $10 \%$ of the total coal consumption in the country. In 1995 , it was estimated that $86 \%$ of the coal used for heating homes, power generation or other purposes in China were directly burned (Linqing, 2001). Therefore it is likely that high concentrations of TGM observed in early hours of January 24 and 25 (Fig. 2) were most likely caused by coal combustion in household and wind direction for those certain periods. During the nighttime winter sampling periods, high concentrations of atmospheric mercury were observed at site 5 (suburban) and site 2 (urban-residential) sampling locations (Figs. 2 and 3). Lower wind speed during night that is typical of Beijing's winter may have increased the residence time of TGM in the boundary layer leading to high TGM concentrations. Due to the use of coal for heating homes in rural sectors (sites 7 and 8), elevated levels of TGM

Table 2

Results of TGM concentrations measured in two sampling locations in Connecticut with Tekran 2537A and the weekly gold trap/GCCVAA analysis as part of the long-term QA/QC program in Connecticut

\begin{tabular}{lllll}
\hline Sampling location & Sampling period & Mean TGM $\left(\mathrm{ng} / \mathrm{m}^{3}\right)$ & & \% Difference \\
\cline { 3 - 5 } & & Tekran 2537A & ERI laboratory & 9.2 \\
\hline East Hartford & September 12-19, 1997 & 2.32 & 2.56 & 3.4 \\
& September 19-26, 1997 & 1.99 & 2.06 & 4.5 \\
& November 7-14, 1997 & 1.67 & 1.75 & 1.8 \\
Mohawk Mountain & December 5-12, 1997 & 1.79 & 1.82 & 0.0 \\
& December 12-19, 1997 & 1.92 & 1.92 & \\
\hline
\end{tabular}




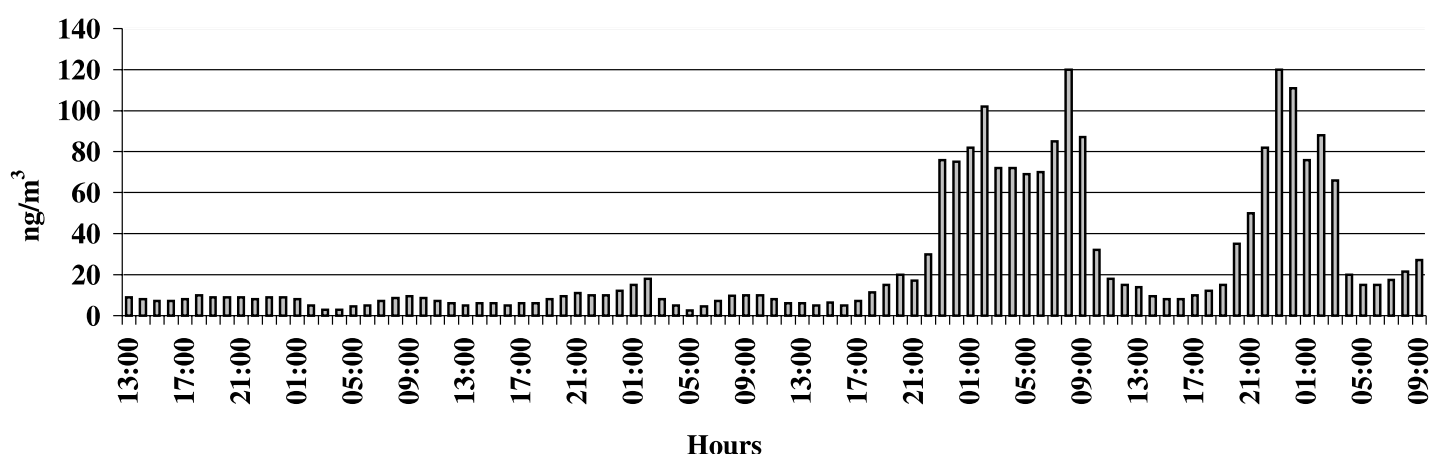

Jan-21

Jan-22

Jan-23

Jan-24

Fig. 2. Hourly ambient concentration of atmospheric mercury at the Xuanwu (site 2) sampling location during winter sampling period.

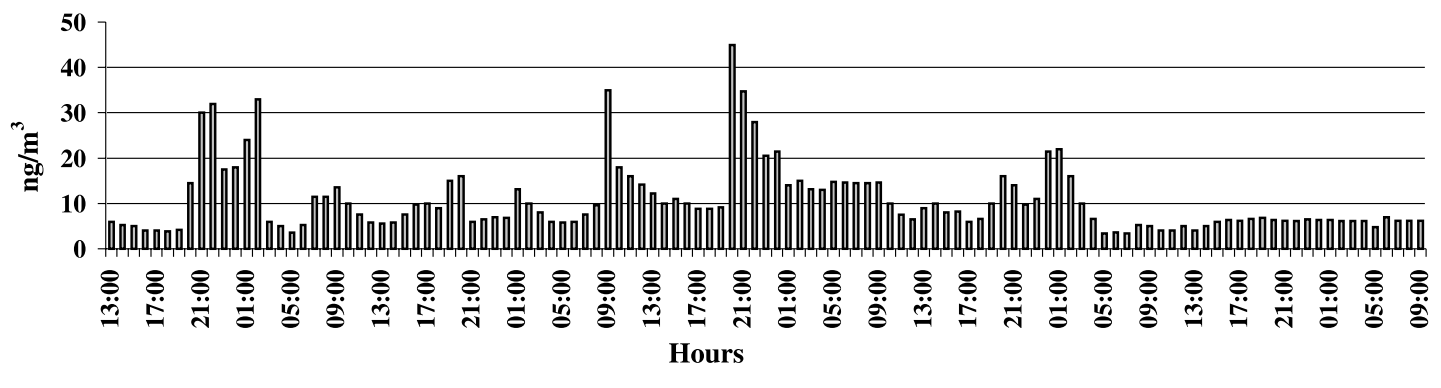

Jan-30

Jan-31

Feb-1

Feb-2

Feb-3

Fig. 3. Hourly ambient concentration of atmospheric mercury at the Research Center (site 5) sampling location during winter sampling period.

concentrations (2-3 times higher than the average marine background concentration of $1.5 \mathrm{ng} / \mathrm{m}^{3}$ for the Northern Hemisphere) were observed. The mean TGM concentrations at site 3 (suburban-industrial) were lower than mean TGM concentrations at site 2 which was an urban residential site in both winter and summer sampling periods. The reason may be due to the fact that the steel plant located in the vicinity of site 3 was equipped with an emission control device and used a mixture of washed and raw coal that had less mercury content than the raw coal used for residential home heating. Through the coal washing process, $80 \%$ of coal ash could be eliminated. Advanced coal washing technologies can substantially reduce sulfur, arsenic and mercury contents of coal but they could become prohibitively expensive. Starting in 1998, the government of China has imposed regulations on the sulfur content of coal used in urban environments and the clean coal technology is continuing to gain progress (Linqing, 2001).

Comparison of the atmospheric mercury concentrations obtained in this study with some historical atmospheric mercury data of other urban and rural locations in the Northern Hemisphere shows that the mean concentration of mercury measured during summer at the Xuanwu $\left(10.5 \mathrm{ng} / \mathrm{m}^{3}\right)$ and Tiananmen Square $(12.7 \mathrm{ng} /$ $\mathrm{m}^{3}$ ) sampling locations were comparable to concentrations of $\sim 10 \mathrm{ng} / \mathrm{m}^{3}$ measured during summer of 1994 at Hayama Point and Chiba University in Nishichiba Station that are both urban locations in Japan. The atmospheric concentration of mercury measured in Tiananmen Square during summer sampling period was also similar to atmospheric mercury concentrations measured in the summer of 1988 in Olympic Park and Han Nam Dong sampling stations located in Seoul, South Korea, at 13 and $15 \mathrm{ng} / \mathrm{m}^{3}$, respectively (Fig. 4).

The atmospheric mercury concentrations measured in the rural sampling locations of this study were similar to rural concentrations measured in Seoul Park and Mountain Stations measured in South Korea (Kim and Kim, 1996) but were slightly higher than the concentrations measured over northeast US and eastern $\mathrm{Ca}$ nadian provinces $\left(1.5-2.1 \mathrm{ng} / \mathrm{m}^{3}\right)$ (Nadim et al., 2001; D'Urso et al., 1998), and Harwell in central region of southern England (1.7 ng/m ${ }^{3}$ ) (Lee et al., 1998). Higher mercury concentrations observed during summer when compared to the winter sampling period in Tiananmen Square and Shijingshan sampling locations were similar to the findings of Nakagawa (1995) at an urban location about $25 \mathrm{~km}$ east of Tokyo, Japan. Sohn et al. (1993) found a similar seasonal trend during their measurement 


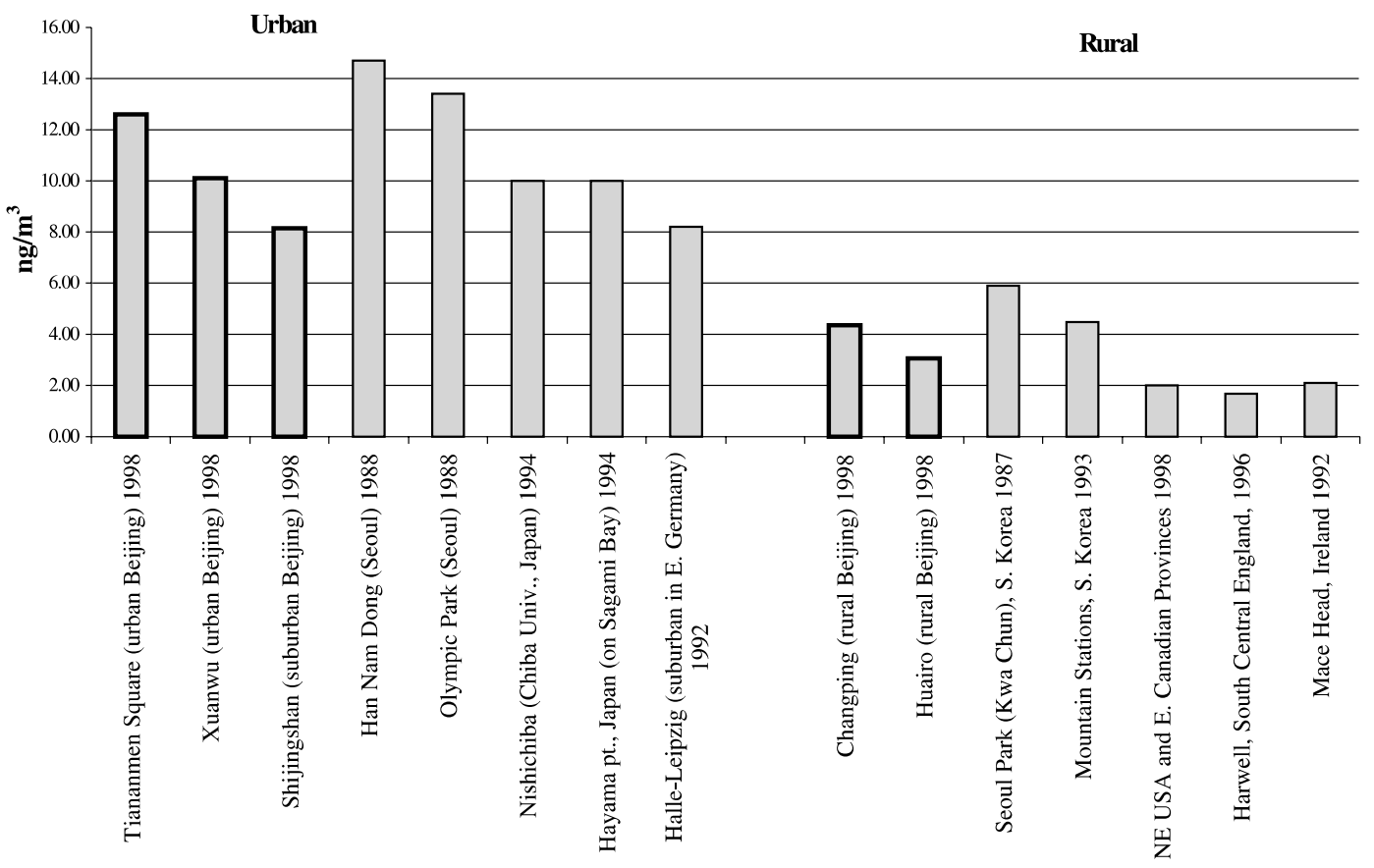

Fig. 4. Comparison of TGM concentration of the urban and rural sectors of Beijing with historical data of other urban and rural locations in the Northern Hemisphere (mean TGM concentration results of this study are indicated with bold lines).

of atmospheric mercury in the Seoul area in South Korea in 1988. Mean concentration of TGM in the Seoul area was $10-40 \%$ higher during summer than winter sampling period. TGM concentrations measured in Shijingshan (suburban Beijing) were very similar to TGM concentrations measured in Halle-Leipzig which is a suburban industrial area in Germany (Ebinghaus et al., 1995).

Elevated episodes of hourly concentrations of atmospheric mercury observed at the Xuanwu sampling location during summer sampling period have also been observed in other urban locations by other researchers. Keeler et al. (1994) studied the atmospheric mercury contamination in the Great Lakes Basin of North America in July and August of 1992 in two rural and one urban sampling locations. During their measurements, average concentration of TGM ranged from 2 to $8.7 \mathrm{ng} / \mathrm{m}^{3}$ and the highest $12-\mathrm{h}$ mean value was $62.7 \mathrm{ng} /$ $\mathrm{m}^{3}$ at the urban (Chicago) sampling site. Monitoring the atmospheric mercury levels in Han Nam Dong quarter of Seoul in South Korea in 1988, Kim and Kim (1996) measured a maximum 3-h mean TGM concentration of $112.8 \mathrm{ng} / \mathrm{m}^{3}$, and an overall mean TGM concentration of $15 \mathrm{ng} / \mathrm{m}^{3}$. Measuring the atmospheric gaseous phase mercury concentration in Hayama Point, an urban area in Japan, during 1978-1986 sampling period, Nakagawa (1995) reported a maximum hourly concentration of 217 $\mathrm{ng} / \mathrm{m}^{3}$ for atmospheric mercury, while the overall mean value was $58.7 \mathrm{ng} / \mathrm{m}^{3}$.

\subsection{Effect of wind speed on atmospheric concentration of mercury}

At the Atmospheric Research Institute (site 6), weather data (wind speed, wind direction, and humidity) were captured every $20 \mathrm{~s}$ by the meteorological station located in the institute. There was a moderate overall negative correlation between the ambient TGM concentrations and the wind speed $(r=-0.65, p<0.0001)$ at site 6 . It should be noted that elevated TGM concentrations caused by emissions were not dispersed due to the absence of high winds. Correlation between mercury concentration data points corresponding to wind speeds lower than $1.5 \mathrm{~m} / \mathrm{s}(r=-0.62)$ was stronger than the correlation between data points and wind speeds higher than $1.5 \mathrm{~m} / \mathrm{s}(r=-0.32)$. Change in mercury concentration decreased with wind speeds higher than $1.5 \mathrm{~m} / \mathrm{s}$ (Fig. 5). Wind speed and mercury concentration data collected at $5 \mathrm{~min}$ are shown in Table 3 . The mercury concentration data were sorted according to wind speed and grouped with an interval of $0.5 \mathrm{~m} / \mathrm{s}$.

\section{Discussion}

4.1. Diurnal changes in atmospheric mercury concentrations

For winter sampling period, air samples taken between $8 \mathrm{AM}$ and $7 \mathrm{PM}$ were categorized as daytime 


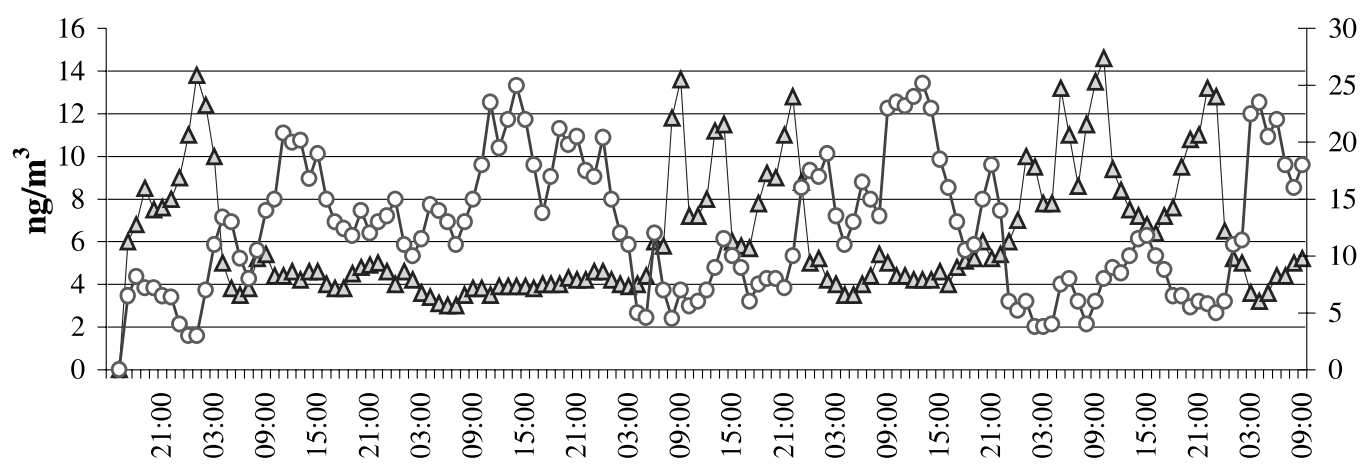

Hours

$\begin{array}{llllll}\text { Jan-16 Jan-17 Jan-18 Jan-21 } & \text { Ja }\end{array}$

Fig. 5. Correlation between wind speed and ambient concentration of TGM at the Atmospheric Research Institute (site 6).

Table 3

Correlation between wind speed and TGM concentration at the Atmospheric Research Institute sampling site

\begin{tabular}{lcclcl}
\hline Wind speed $(\mathrm{m} / \mathrm{s})$ & Data points & $\begin{array}{l}\text { Percentage of } \\
\text { occurrence }\end{array}$ & $\begin{array}{l}\text { Average conc. } \\
\left(\mathrm{ng} / \mathrm{m}^{3}\right)\end{array}$ & $\begin{array}{l}\text { Max. conc. (5 min) } \\
\left(\mathrm{ng} / \mathrm{m}^{3}\right)\end{array}$ & $\begin{array}{l}\text { Min. conc. (5 min) } \\
\left(\mathrm{ng} / \mathrm{m}^{3}\right)\end{array}$ \\
\hline$<0.5$ & 106 & 6.7 & 9.90 & 25.7 & 3.9 \\
$0.5-1.0$ & 490 & 31.1 & 8.19 & 16.4 & 2.9 \\
$1.0-1.5$ & 498 & 31.6 & 4.71 & 14.1 & 2.8 \\
$1.5-2.0$ & 252 & 16.0 & 4.12 & 7.4 & 2.9 \\
$2.0-2.5$ & 166 & 10.5 & 3.88 & 5.4 & 2.8 \\
$2.5-3.0$ & 53 & 3.4 & 3.97 & 9.7 & 3.2 \\
$>3.0$ & 12 & 0.8 & 4.26 & 25.7 & 3.0 \\
Overall & 1577 & 100.0 & 5.93 & 2.8 \\
\hline
\end{tabular}

samples and samples taken between 7 PM and 8 AM were considered as nighttime samples. For summer sampling period, air samples taken between $7 \mathrm{AM}$ and 8 PM were categorized as daytime samples and samples taken between 8 PM and 7 AM were considered as nighttime samples. At site 5, the mean TGM concentration during night hours $\left(12.4 \mathrm{ng} / \mathrm{m}^{3}\right)$ was $44 \%$ higher than the mean TGM concentration $\left(8.6 \mathrm{ng} / \mathrm{m}^{3}\right)$ during daytime hours. In the other two (site 4 and site 6 ) suburban sampling locations there was no significant difference between the daytime and nighttime TGM concentrations (Table 1). At the Xuanwu (urban-residential) sampling location, mean concentrations of TGM during nighttime were higher than daytime sampling hours for both winter and summer sampling periods (Table 1). At the Tiananmen sampling location the mean TGM concentration for daytime sampling hours was $21 \%$ higher than the nighttime sampling hours during the summer sampling period. At the suburban- industrial site (site 3), mean TGM concentration during nighttime-summer was $23 \%$ higher than the daytime concentrations. No significant difference was observed between the daytime and nighttime TGM concentrations at the two rural (site 7 and site 8) sites during winter and summer sampling periods. Highest $1-\mathrm{h}$ average TGM concentration was observed at the Xuanwu site $\left(120 \mathrm{ng} / \mathrm{m}^{3}\right)$ at $11 \mathrm{PM}$, during the winter sampling hours.

4.2. Effect of coal consumption in winter, solar radiation and temperature in summer on atmospheric concentration of mercury

Pirrone et al. (1996) studied the regional differences in worldwide emissions of mercury to the atmosphere. They stated that coal combustion was the dominant source of human-related atmospheric mercury contamination in Asia ( $42 \%)$. In assessing worldwide 
contamination of air by trace metals, Nriagu and Pacyna (1988) stated that the combustion of hard coal, lignites and brown coal in electric power plants and in industrial, commercial and residential furnaces was the major source of atmospheric mercury contamination from anthropogenic sources. The mercury content of coal from northeastern China was measured by Wang et al. (2000) and it ranged from 0.003 to $1.649 \mathrm{mg} / \mathrm{kg}$ (mean $=0.158 \mathrm{mg} / \mathrm{kg}$ ).

The Hg speciation from coal combustion depends on the type of coal and the combustion conditions. Gaseous phase mercury $\left(\mathrm{Hg}^{0}\right.$ or $\left.\mathrm{Hg}^{2+}\right)$ comprises of $90-99 \%$ of total mercury emissions and particulate mercury forms a small portion of the total stack emissions. Yokoyama et al. (2000) studied mercury emissions from a coal-fired power plant in Japan. Measuring the stack concentration, they found that more than $99 \%$ of mercury in the stack emissions were in gaseous form and the proportion in the particulate form was extremely low. Gibb et al. (2000) studied the mercury speciation of four UK coals with a $1 \mathrm{MW}_{\text {th }}$ combustion test facility. They found that $80 \%$ of the vapor phase mercury was present in the oxidized $\left(\mathrm{Hg}^{2+}\right)$ form and a negative correlation existed between mercury retention in dust and the flue gas temperature.

High concentration of TGM in five of the seven sampling locations in Beijing may have been caused by intense use of coal burning in winter to heat homes and the lack of emission control devices. High TGM concentrations were also observed in summer (September) sampling hours at Xuanwu, Tiananmen, and Shijingshan sampling locations (Table 1). The average (day and night) minimum TGM concentrations in Xuanwu (urban residential) and Tiananmen Square (city center) during the summer sampling period were significantly higher than the winter sampling period (Table 1). There were a few factors contributing to high TGM concentrations during the September sampling period. Coal is not used for heating homes during summer in Beijing area, but it is used for production of hot water and cooking purposes. There are factors other than coal combustion that contribute to elevated TGM levels during summer. Average low and high temperatures recorded for January and February in the meteorological station at the Atmospheric Research Institute (site 6) were -8 and $4{ }^{\circ} \mathrm{C}$, respectively. Average low and high temperatures in August and September were 18 and 28 ${ }^{\circ} \mathrm{C}$, respectively. Due to the combustion of coal for heating homes and buildings, large quantities of mercury are emitted to the atmosphere during wintertime. Low temperatures and precipitation bring a portion of the emitted mercury back to the ground in the form of dry or wet deposition. During summer hours when the heat index is high, mercury in the soil evaporates back to the atmosphere, causing an increase in atmospheric mercury concentrations. However, this phenomenon needs fur- ther investigation by measuring the soil flux of mercury and its interaction with TGM in urban sectors of Beijing during warm periods. Measuring the water-air and soilair exchange rate of TGM in the summer of 1995 in the southern part of Quebec, Canada, Poissant and Casimir (1998) found that mercury flux from a grass covered soil was relatively constant $\left(\sim 2-3 \mathrm{ng} / \mathrm{m}^{2} \mathrm{~h}\right)$ in the temperature range of $10-20^{\circ} \mathrm{C}$. In the temperature range of 20 $30{ }^{\circ} \mathrm{C}$ mercury flux rose to $\sim 7-8 \mathrm{ng} / \mathrm{m}^{2} \mathrm{~h}$. They also found that mercury flux was positively correlated with wind speed $\left(r^{2}=0.3906\right)$. Capri and Lindberg (1997) conducted a study on the effect of sunlight on the emission of elemental mercury from soils amended with municipal sewage sludge. They found a strong positive correlation between the soil temperature and $\mathrm{Hg}^{0}$ emissions. They also concluded that the dominant factor affecting soil $\mathrm{Hg}^{0}$ emissions was solar radiation. At one of their sites, they measured soil $\mathrm{Hg}$ emissions from July 26 to 27,1995 . During this sampling period, highest $\mathrm{Hg}^{0}$ fluxes from soil occurred between $10 \mathrm{AM}$ and $3 \mathrm{PM}$. They suggested that reduced $\mathrm{Hg}$ was oxidized to volatile $\mathrm{Hg}^{0}$ in the upper layer soil due to sunlight and abiotic reduction of $\mathrm{Hg}^{2+}$ and this phenomenon was highest on exposed fields. The same phenomenon investigated by Capri and Lindberg (1997), and Poissant and Casimir (1998) could partially be responsible for elevated levels of atmospheric mercury in Beijing during summer hours.

\subsection{Effect of wind frequencies on atmospheric mercury flux}

The 5-min mercury concentration data were sorted by wind direction and grouped for every $10^{\circ}$ as discussed in Section 2.4 (Table 3). All the measured data at site 6 (Atmospheric Research Institute) were grouped together and used in Table 3. During the monitoring period, the prevalent wind was from the $20^{\circ}$ to the $140^{\circ}$ sector, with maximum frequency occurring at $70^{\circ}$ (Fig. 6).

The highest mean concentration of mercury occurred when the wind direction was in the northeast direction (30-50 $0^{\circ}$ sectors). In this range of sectors, the average wind speed was lower than $1.0 \mathrm{~m} / \mathrm{s}$. The lowest average mercury concentration occurred when the wind was in the $230-260^{\circ}$ southwest direction. In this range of sectors, the average wind speed was higher than $1.5 \mathrm{~m} / \mathrm{s}$ (Fig. 7).

The relative flux parameter $(F)$ was measured using the modified version of a mass balance equation used by Poissant and Casimir (1998) for computation of mercury flux with the dynamic flux chamber technique. If site 6 was considered as a mercury receptor, the relative flux parameter $(F)$ measuring the mercury flux in all directions could be written as

$F_{i}=\left(C_{i}-C_{\text {min }}\right) \times \mathrm{WS}_{i} \times \mathrm{WF}_{i}$, 


\section{$\multimap-$ Relative Flux Distribution x 1/6 $\quad-\%$ Wind Occurrence Frequencies}

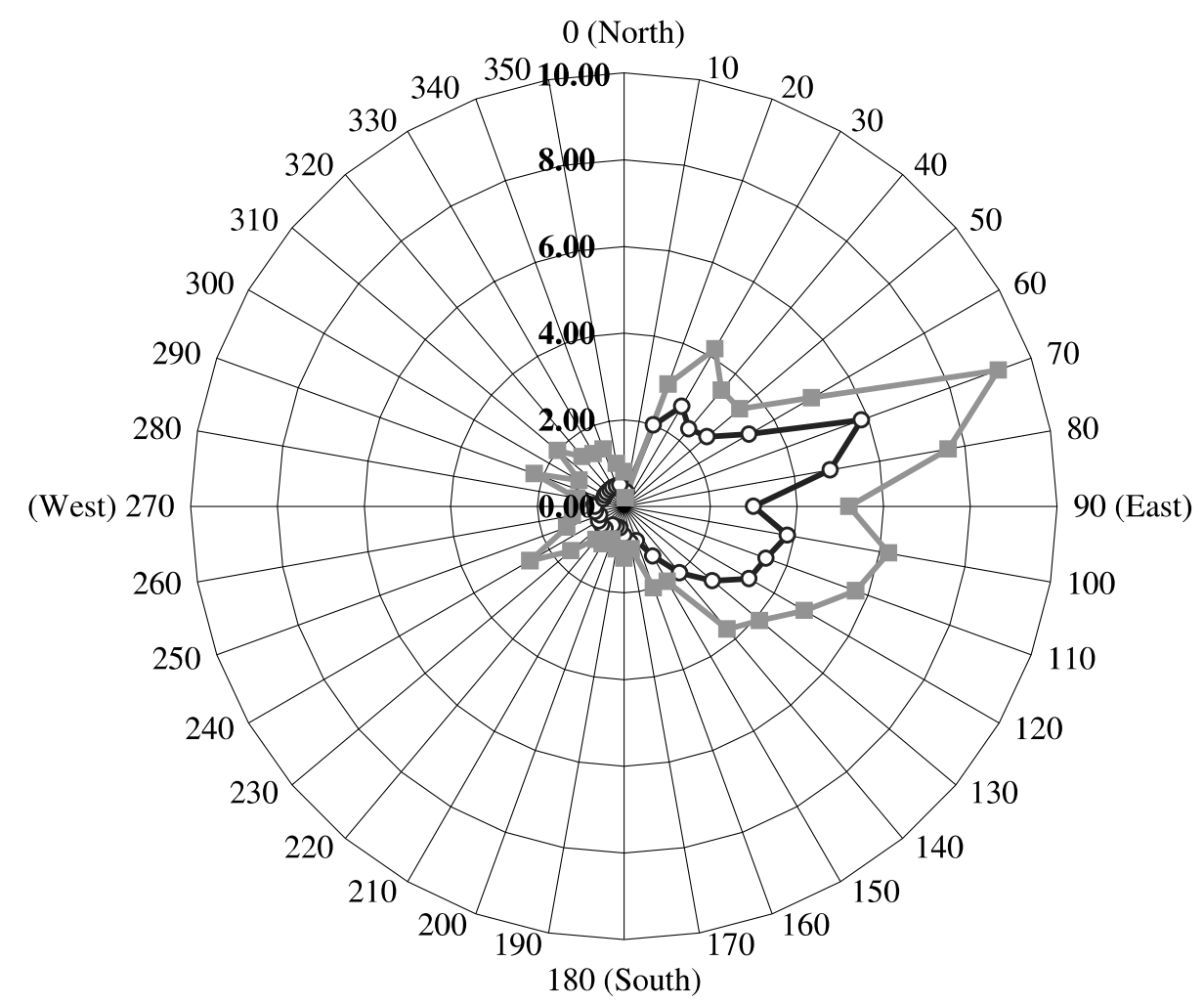

Fig. 6. Comparison of relative mercury flux with wind occurrence frequencies at the Atmospheric Research Institute (site 6).

where $F_{i}$ is the relative flux parameter for a certain direction ( $\left.\mathrm{ng} / \mathrm{m}^{2} \mathrm{~s} \%\right), C_{i}$ is the mean ambient air concentration of mercury $\left(\mathrm{ng} / \mathrm{m}^{3}\right), C_{\min }$ is the minimum concentration at site 6 (used as background concentration) $\left(\mathrm{ng} / \mathrm{m}^{3}\right), \mathrm{WS}_{i}$ is the average wind speed at any direction, used as a linear flow rate of mercury flux $(\mathrm{m} / \mathrm{s})$, and $\mathrm{WF}_{i}$ is the percentage wind direction frequency (\%).

Concentration multiplied by the flow rate $\left(\mathrm{WS}_{i}\right)$ on the right-hand side of Eq. (1) was relatively constant, making the relative flux of mercury proportional to the wind frequency in different directions. Therefore, during the sampling period at site 6 , the quantity of TGM transported to or from the sampling site was mainly influenced by the duration and frequency of wind occurrence from certain directions (Fig. 6).

\section{Conclusion}

Atmospheric mercury was monitored for short durations (3-6 days) at seven sampling locations in Beijing municipality during January, February and September of 1998. High concentrations of TGM were observed in urban sections (urban residential and city center) of Beijing during daytime and nighttime sampling hours in summer and winter sampling periods with a few episodes of very high levels of TGM concentrations. Highest concentration of TGM was measured in an urban-residential section of Beijing (Xuanwu) $\left(120 \mathrm{ng} / \mathrm{m}^{3}\right)$ in January, suggesting that a positive correlation existed between high atmospheric mercury and coal consumption.

If, for each sampling location, the minimum concentration of TGM is considered as the background level of mercury for that sampling location, the collected data showed that at Xuanwu, and Tiananmen Square sampling sites, the background levels of TGM concentrations in September were higher than the January and February sampling periods (Table 1). Although during summer coal is not used for heating purposes, higher TGM concentrations may be due to evaporation of soilbound mercury caused by high temperatures and solar radiation. To verify this assumption, future studies should include longer monitoring periods of TGM 
$\longrightarrow-$ Wind Speed x $4(\mathrm{~m} / \mathrm{sec})$

$\Delta \mathrm{Hg}$ Concentration $\left(\mathrm{ng} / \mathrm{m}^{3}\right)$

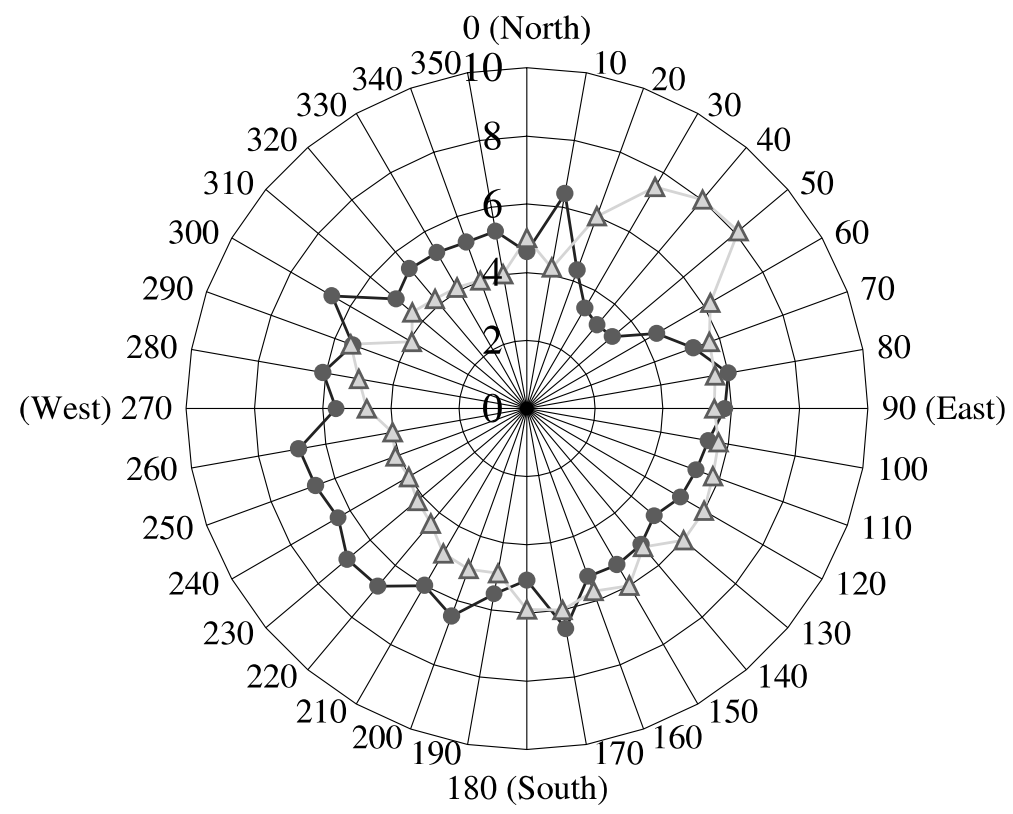

Fig. 7. Wind speed and TGM concentration at the Atmospheric Research Institute (site 6).

concentration in conjunction with measurements of soil fluxes of mercury in populated urban and industrial locations.

Continuous monitoring can provide more detailed information regarding ambient air mercury pollution trends in populated cities and industrial regions of China. Hourly averages seem to be a sufficient reflection of the temporal and diurnal variation of mercury concentration. TGM concentration data combined with wind speed and wind direction can aid in characterizing mercury pollution. Wind speed appears to be a major factor in mercury concentration variation. Lower wind speed may have increased the residence time of TGM in the boundary layer leading to high TGM concentrations during certain sampling hours. The transporting air mass at higher wind velocities could have diluted and dispersed TGM in the boundary layer resulting in lower TGM concentrations.

\section{Acknowledgements}

Sampling equipment for this work was provided by the Connecticut Department of Environmental Protection. The authors would like to thank the Chinese
Academy of Sciences for their full cooperation and technical support.

\section{References}

Capri, A., Lindberg, S.E., 1997. Sunlight mediated emission of elemental mercury from soil amended with municipal sewage sludge. Environ. Sci. Technol. 31 (7), 20852091.

D’Urso, J., Martin, A., Tatsutani, M., 1998. Inventory of anthropogenic mercury emissions in the Northeast. In: Round, M. (Ed.), Mercury Study: Northeast States and Eastern Canadian Provinces (Chapter V, 25 pp.).

Ebinghaus, R., Kock, H.H., Jennings, S.G., McCartin, P., Orren, M.J., 1995. Measurements of atmospheric mercury concentrations in northwestern and central Europe-comparison of experimental data and model results. Atm. Environ. 29 (22), 3333-3344.

Fitzgerald, W.F., Engstrom, D.R., Mason, R.P., Nater, E.A., 1998. The case for atmospheric mercury contamination in remote areas. Environ. Sci. Technol. 32 (1), 1-7.

Gibb, W.H., Clarke, F., Mehta, A.K., 2000. The fate of coal mercury during combustion. Fuel Process. Technol. 65-66, 365-377.

Godley, F.G., 1997. Coal in a Competitive Electric Market. Office of Fossil Energy, United States Department of 
Energy, Washington, DC (http://www.fe.doe.gov/events/ speeches/edaily).

Keeler, G.J., Hoyer, E., Lamborg, C.H., 1994. Measurements of atmospheric mercury in the Great Lakes basin. In: Watras, C.J., Huckabee, J.W. (Eds.), Mercury Pollution: Integration and Synthesis. Lewis Publishers/CRC Press, Ann Arbor, MI, pp. 231-241.

Kim, K.H., Kim, M.Y., 1996. Preliminary measurements of atmospheric mercury in mountainous regions of Korea. J. Environ. Sci. Health A 31 (8), 2023-2032.

Lee, D.S., Dollard, G.J., Pepler, S., 1998. Gas-phase mercury in the atmosphere of the United Kingdom. Atm. Environ. 32 (5), 855-864.

Lin, C.J., Pehkonen, S.O., 1999. The chemistry of atmospheric mercury: a review. Atm. Environ. 33, 2067-2079.

Linqing, J., 2001. Rational and Clean Coal Use in China. World Bank of the East Asia and Pacific Division: Environmental Affairs. (http://www.chinaenvironment.net/sino).

Nadim, F., Perkins, C., Liu, S., Carley, R., Hoag, G.E., 2001. Long-term investigation of atmospheric mercury contamination in Connecticut. Chemosphere 45, 1033-1043.

Nakagawa, R., 1995. Studies on the levels in atmospheric concentrations of mercury in Japan. Chemosphere 32 (2), 2669-2676.

Nriagu, J.O., 1989. A global assessment of natural sources of atmospheric trace metals. Nature 338, 47-49.
Nriagu, J.O., Pacyna, J.M., 1988. Quantitative assessment of worldwide contamination of air, water and soil by trace metals. Nature 333, 134-139.

Pirrone, N., Keeler, G.J., Nriagu, J.O., 1996. Regional difference in worldwide emissions of mercury to the atmosphere. Atm. Environ. 30 (17), 2981-2987.

Poissant, L., Casimir, A., 1998. Water-air and soil-air exchange rate of total gaseous mercury measured at background sites. Atm. Environ. 32 (5), 883-893.

Sohn, D.H., Jung, W.T., Kim, D., 1993. Distribution of total mercury in the ambient atmosphere of Seoul and its diurnal, monthly and altitudinal variations. Jpn. J. Toxicol. Environ. Health 39, 582-588.

Tatsutani, M., 1998. Executive summary. In: Round, M. (Ed.), Mercury Study: Northeast States and Eastern Canadian Provinces, pp. 1-8.

Wang, Q., Shen, W., Ma, Z., 2000. Estimation of mercury emission from coal combustion in China. Environ. Sci. Technol. 34 (13), 2711-2713.

Xu, X., Yang, X., Miller, D., Helble, J., 1999. A regional scale modeling study of atmospheric transport, transportation, and deposition of mercury. I. Model development and validation. Atm. Environ. 33, 4345-4355.

Yokoyama, T., Asakura, K., Matsuda, H., Ito, S., Noda, N., 2000. Mercury emissions from a coal-fired power plant in Japan. Sci. Tot. Environ. 259, 97-103. 